\title{
Adsorbtion of sodium tridecanoate on copper from aqueous solutions and copper protection from atmospheric corrosion
}

\author{
Yu.I. Kuzntesov, I.A. Kuznetsov and N.P. Andreeva \\ A.N. Frumkin Institute of Physical Chemistry and Electrochemistry, Russian Academy \\ of Sciences, Leninsky pr. 31, Moscow, 119071 Russian Federation \\ E-mail: kuznetsov@ipc.rssi.ru
}

\begin{abstract}
The adsorption and protective effect of sodium tridecanoate $\mathrm{CH}_{3}\left(\mathrm{CH}_{2}\right)_{11} \mathrm{COONa}\left(\mathrm{NaC}_{13}\right)$ on copper and the possibility of increasing the effectiveness of protection by joint use with a trialkoxysilane (TAS) were investigated. A set of electrochemical, ellipsometric and corrosion tests was carried out on samples of M1 copper (copper content > 99.9\%). From an analysis of the anodic polarization curves of copper from solutions containing $\mathrm{NaC}_{13}$, it follows that when the inhibitor concentration is $>0.07 \mathrm{mmol} / \mathrm{l}$, the current density of copper active dissolution decreases and spontaneous passivation of the electrode occurs with a shift in the value of the pitting potential $E_{\text {pit }}$ in the positive direction. With an increase in the concentration of the inhibitor, the value of $E_{\text {pit }}$ increases while the anodic current density decreases. When the concentration of the inhibitor in the solution is $1.6 \mathrm{mmol} / 1$ or more, the value of $E_{\text {pit }}$ shifts to the oxygen evolution region. Studies of $\mathrm{NaC}_{13}$ using the ellipsometric method showed that the adsorption of the inhibitor starts at very low concentrations, viz., $0.01 \mathrm{nmol} / 1$. Adsorption is described by the Temkin equation with an adsorption free energy of $67 \mathrm{~kJ} / \mathrm{mol}$. In comparison with sodium oleyl sarcosinate $\mathrm{CH}_{3}\left(\mathrm{CH}_{2}\right)_{7} \mathrm{CH}=\mathrm{CH}\left(\mathrm{CH}_{2}\right)_{7} \mathrm{CON}\left(\mathrm{CH}_{3}\right) \mathrm{CH}_{2} \mathrm{COONa}$ (SOS) and sodium laurate $\mathrm{CH}_{3}\left(\mathrm{CH}_{2}\right)_{10} \mathrm{COONa}\left(\mathrm{NaC}_{12}\right)$, adsorption begins at lower concentrations. Sodium tridecanoate adsorption on copper is polymolecular. Accelerated corrosion tests with daily moisture condensation on copper pretreated with an inhibitor solution at $60^{\circ} \mathrm{C}$ for 5 minutes were carried out. It was shown a protective mixture of $\mathrm{NaC}_{13}$ and TAS significantly increased the time until the appearance of the first corrosion site.
\end{abstract}

Key words: sodium tridecanoate, inhibitor, corrosion, passivity, adsorption, ellipsometry, copper.

Received: November 1, 2018. Published: November 29, 2018

doi: $\underline{10.17675 / 2305-6894-2018-7-4-11}$

Currently, copper and its alloys are important structural materials that are widely used in heat exchange equipment, electrical devices and microelectronics. This is largely due to the properties of copper - low resistivity, high thermal conductivity and mechanical strength. Copper and copper alloys have relatively high corrosion resistance, but in a humid atmosphere or in aqueous solutions of corrosive salts they start to dull and corrode.

One of the effective methods to increase the resistance of copper that is widely reflected in monographs and scientific reviews [1-9] is to use organic corrosion inhibitors 
(CI). Many CIs form thin films on the surface of copper that can reliably protect it from corrosion in neutral environments, including a humid atmosphere.

One of the most effective and popular classes of copper CIs are azoles, in particular, 1,2,3-benzotriazole and its derivatives [2-8]. Carboxylic acids and their salts, which differ from azoles in greater environmental safety and availability, can also serve as copper CIs [1, 9-14]. Generally, their higher homologs are more effective. They have increased hydrophobicity, which contributes to their better adsorption from aqueous solutions. However, with an increase in the chain length of carboxylates, their critical micelle concentration $(\mathrm{CMC})$ decreases, which may reduce the adsorption of $\mathrm{CI}$ anions from an aqueous solution.

It is known [15-17] that corrosion protection by ultrathin coatings formed by carboxylates on some metals (zinc, aluminum alloys) can be improved by joint use with various trialkoxysilanes (TAS).

The purpose of this work is to study the adsorption of the sodium salt of tridecanoic acid $\mathrm{CH}_{3}\left(\mathrm{CH}_{2}\right)_{11} \mathrm{COOH}\left(\mathrm{NaC}_{13}\right)$ on copper and the protection of this metal from atmospheric corrosion, as well as the possibility of increasing its efficiency by the joint use of the carboxylate CI with TAS.

\section{Experimental}

Electrochemical, ellipsometric, and corrosion tests were performed on samples of M1 copper $(\geq 99.9 \%$ copper). Inhibitor solutions were prepared by dissolving tridecanoic acid in water followed by neutralizing it with an equivalent amount of $\mathrm{NaOH}$. The borate buffer solution with $\mathrm{pH} 7.36$ containing $10 \mathrm{mmol} \mathrm{NaCl}$ served as the background solution.

A sample for electrochemical studies was made as a cylindrical copper electrode embedded in a Teflon holder. The working surface of the electrode was the base of the cylinder with an area of $0.75 \mathrm{~cm}^{2}$. The working surface was cleaned successively with an abrasive paper with grit P600 and P1000, degreased with acetone, and further treated with magnesium oxide on felt until a drop of water covered the entire working surface of the electrode.

Anodic polarization curves (APC) of copper were recorded in a glass three-electrode cell with electrode spaces separated with a glass filter, using an IPC-Pro MF potentiostat. A silver/silver chloride reference electrode and a graphite auxiliary electrode were used. All measured electrode potentials were recalculated to the normal hydrogen scale. The electrode was placed in a cell with $60 \mathrm{ml}$ of the background solution and kept for 15 minuets at $E=-0.6 \mathrm{~V}$ in order to reduce the primary copper oxide formed in air. After that, polarization was turned off for 15 minutes. During this time, the free corrosion potential ceased to change and assumed a specific value, after which the electrode was anodically polarized at a potential scan rate of $0.2 \mathrm{mV} / \mathrm{s}$.

The adsorption of $\mathrm{NaC}_{13}$ from borate buffer with $\mathrm{pH} 7.4$ on a copper electrode was

studied by the reflective ellipsometry method (REM) in a specially designed cell that 
allows electrochemical and ellipsometric studies to be conducted simultaneously. The method and application of REM for studying the adsorption of organic compounds on copper are detailed in [18]. The ellipsometric experiment involved measuring the phase angle $\Delta$ and polarization angle $\psi$ of light reflected from the electrode surface.

It follows from the REM theory that the changes in the ellipsometric angle $\delta \Delta$ are proportional to the thickness of the growing film $\mathrm{d}$ within $10 \mathrm{~nm}$. There is a relationship between the experimentally determined changes in the $\Delta$ angle and the degree of coverage of the surface with inhibitor particles $(\theta)$ at various concentrations $C_{\text {in }}$ of the adsorbate in the solution:

$$
\theta=\beta \delta \Delta=\beta\left(\Delta-\Delta_{0}\right),
$$

where $\beta$ is the parameter determined from the experimental dependence on the specifically selected adsorption isotherm of the adsorbate, $\Delta_{0}$ is the angle related to the original surface, and $\Delta$ is the current angle. A platinum auxiliary electrode and a RUDOLPH RESEARCH ellipsometer were used. A helium-neon laser with a wavelength of $640 \mathrm{~nm}$ served as the radiation source.

The plot of $|\delta \Delta|$ variation versus $\lg C_{\text {in }}$ was converted to the adsorption isotherm. The experimental curve in the range of medium degrees of coverage $(\theta)$ is described by the Temkin logarithmic isotherm:

$$
\theta=1 / f\left(\ln B_{\max } C\right),
$$

where $f$ is the surface energy inhomogeneity factor and $B$ is the adsorption equilibrium constant related to the free adsorption energy $\left(-\Delta G_{\mathrm{A}}^{0}\right)$ by the relationship $B=\left[\exp \left(-\Delta G_{\mathrm{A}}^{0} / R T\right)\right] / 55.5$.

To perform an ellipsometric experiment, an electrode was cleaned on abrasive paper to the mirror surface, then polished on felt impregnated with calcium oxide. The criterion for preparing the electrode at this stage was that a drop of water covered the entire copper surface and held onto it. The electrode was placed in a cell and kept for $30 \mathrm{~min}$ at $E=$ $-0.6 \mathrm{~V}$ to restore the primary oxide film, then $E$ was switched to $0.00 \mathrm{~V}$ and the electrode was oxidized for 1.5 hours to stabilize its surface. After 1.5 hours, the $\Delta$ angle ceased to change. This was taken for surface stabilization and a CI concentrate was introduced into the cell, after which the $\Delta$ angle was measured. By conducting these experiments with different inhibitor concentrations $C_{\mathrm{in}}$, we obtained the plot of $\Delta$ versus $\lg C_{\mathrm{in}}$.

Corrosion tests were carried out in cells with a volume of 0.5 liters, at the bottom of which $50 \mathrm{ml}$ of hot water $\left(60^{\circ} \mathrm{C}\right)$ was poured. Preliminarily, copper samples (plates with a size of $30 \times 70 \mathrm{~mm}$ ) were polished on abrasive paper with grit P1000 to a mirror finish and degreased with acetone. Then they were kept in an aqueous solution of an inhibitor with a temperature of $t=60^{\circ} \mathrm{C}$ for $5 \mathrm{~min}$. After that, the cell was closed with a lid on which the copper samples were hung. As a result of the natural cell cooling, water vapor condensed on the walls and on the samples. Every day the cooled water was replaced by hot water. 
The samples were examined daily to determine the time until the first signs of copper corrosion.

\section{Results and Discussion}

Figure 1 shows the isotherm of the changes in $\Delta$ angle versus $\lg C_{\text {in }}$ for $\mathrm{NaC}_{13}$, oleyl sarcosinate $\mathrm{CH}_{3}\left(\mathrm{CH}_{2}\right)_{7} \mathrm{CH}=\mathrm{CH}\left(\mathrm{CH}_{2}\right)_{7} \mathrm{CON}\left(\mathrm{CH}_{3}\right) \mathrm{CH}_{2} \mathrm{COONa}$ (SOS) and sodium laurate $\mathrm{C}_{11} \mathrm{H}_{23} \mathrm{COONa}\left(\mathrm{NaC}_{12}\right)$. Studies of $\mathrm{NaC}_{13}$ adsorption by the ellipsometric method showed that the adsorption of this inhibitor on oxidized copper surface begins at somewhat lower concentrations than in the case of $\mathrm{NaC}_{12}$ adsorption. This could be expected, given that the hydrophobic alkyl radical in the case of $\mathrm{NaC}_{13}$ is by one methylene group larger than $\mathrm{NaC}_{12}$. After the formation of a conditional monolayer indicated by a plateau on the plot of $(-\delta \Delta)$ versus $\lg C_{\text {in }}$ for $\mathrm{NaC}_{13}$, the $\Delta$ angle continues to change, which is characteristic of further polymolecular adsorption.

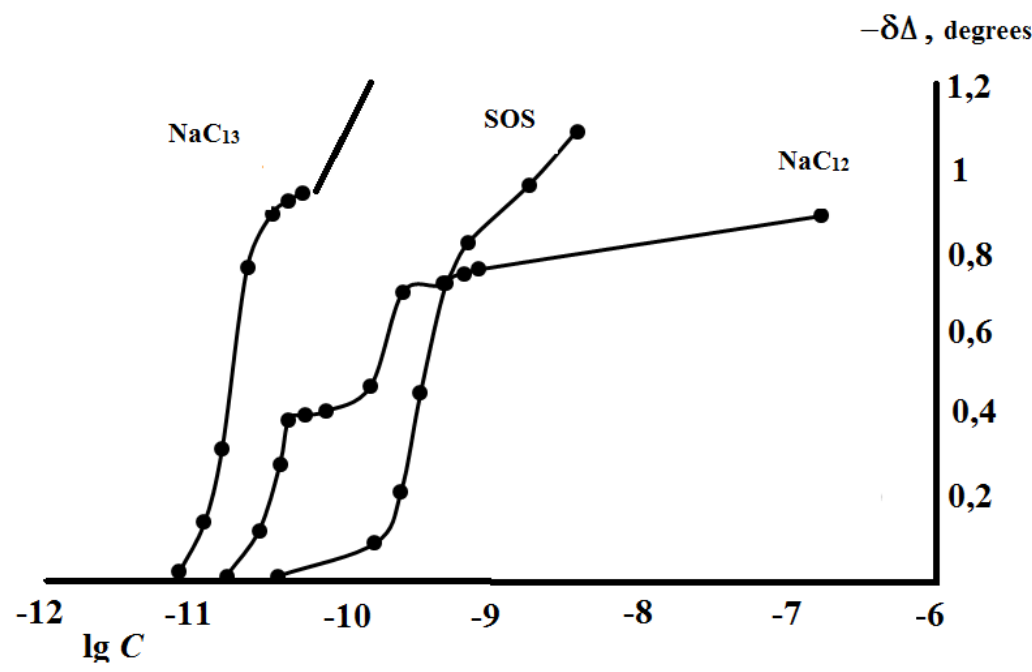

Figure 1. Isotherms of the ellipsometric angle $\Delta$ variation upon the adsorption of sodium tridecanoate, sodium oleyl sarcosinate and sodium laurate on $\mathrm{Cu}$ at $E=0.0 \mathrm{~V}$.

To describe the adsorption in the range of medium $\theta$ of the monomolecular layer nearest to the copper surface, the logarithmic Temkin isotherm is applicable (2). Calculations for $\mathrm{NaC}_{13}$ gave the value $\left(-\Delta G_{\mathrm{A}}^{0}\right)=67 \pm 3 \mathrm{~kJ} / \mathrm{mol}$. Comparison of the results of $\mathrm{NaC}_{13}$ adsorption measurements with those of the best CIs of the fatty series studied previously ( $\mathrm{SOS}$ and $\mathrm{NaC}_{12}$ ) suggests the important role of the hydrophobicity of the anion in its adsorption on oxidized copper. The hydrophobicity of organic molecules is estimated by the logarithm of the distribution coefficient $\lg P$ that is calculated from the data on the distribution of the chemical compound in the system of two immiscible liquids, octanolwater [19]. The surface activity of anions of organic acid salts depends on the $\mathrm{pH}$ of aqueous solutions, therefore, their hydrophobicity is characterized by the $\lg D$ value, hydrophobicity constant of the dissociated form, which is calculated taking into account 
the $\mathrm{p} K_{\mathrm{a}}$ of the corresponding acids, where $\lg P$ is the hydrophobicity constant of the neutral compound [20]:

$$
\lg D=\lg P-\lg \left[1+10^{\left(\mathrm{pH}-\mathrm{p} K_{\mathrm{a}}\right)}\right]
$$

It is quite expected that $\mathrm{NaC}_{12}$ anions are inferior in adsorption capacity to their $\mathrm{NaC}_{13}$ analogues for the above reasons. The most hydrophobic $\mathrm{OCH}$ anions are very close in size $\left(-\Delta G_{\mathrm{A}}^{0}\right)$ to the anions of lauric acid (almost equal within the reproducibility of the measurements). However, their protective effect, which is manifested in the stabilization of the passive state of copper, i.e. the value $\Delta E=E_{\text {pit }}^{\text {in }}-E_{\text {pit }}^{\text {background }}$ calculated from the anodic polarization curves, shows that $\mathrm{SOS}$ is a more effective $\mathrm{CI}$ than $\mathrm{NaC}_{12}$. It can be assumed that the mechanism of protection of passive copper from the corrosive action of the chloride ion by SOS anions and sodium alkyl carboxylates is not quite the same. It is possible that the SOS radical creates conformational difficulties in the formation of a compact adsorption layer on copper. In this regard, of particular interest is a comparison of the effect of the two nearest homologues $\left(\mathrm{NaC}_{12}\right.$ and $\left.\mathrm{NaC}_{13}\right)$ on the anodic dissolution of copper in borate buffer containing $10 \mathrm{mM} \mathrm{NaCl}$.

From the anodic polarization curves of copper in borate solutions containing $\mathrm{NaC}_{13}$, it can be seen that at $C_{\text {in }}>0.07 \mathrm{mmol} / \mathrm{l}$, the current density of active dissolution of copper decreases and spontaneous passivation of the electrode occurs with a shift of the $E_{\text {pit }}$ value in the positive direction (Figure 2). With an increase in $C_{\mathrm{in}}$, the value of $E_{\mathrm{pit}}$ increases and the anodic current density decreases. If the inhibitor concentration in the solution is up to $1.6 \mathrm{mmol} / \mathrm{l}$ or more, the value of $E_{\text {pit }}$ shifts to the oxygen evolution region.

The difference $\Delta E$ between the $E_{\text {pit }}$ measured in solutions containing an inhibitor and in the background is considered to be a measure of the effectiveness of the inhibitor in the ability to stabilize the passivation of metal electrodes. Table 1 shows a comparison of the effectiveness of $\mathrm{NaC}_{13}$ with that of $\mathrm{NaC}_{12}$ and SOS. As follows from the table, an increase in the length of the hydrocarbon radical (by a $-\mathrm{CH}_{2}-$ moiety) significantly shifts the $E_{\text {pit }}$ in the anodic direction at the same $C_{\text {in }}$.

Table 1. Physicochemical characteristics $\left(\lg P, \mathrm{p} K_{\mathrm{a}}, \lg D\right)$, protective effects and parameters of adsorption of corrosion inhibitors on copper in borate buffer with $\mathrm{pH}$ 7.4. The results for $\mathrm{SOS}$ and $\mathrm{NaC}_{12}$ were obtained previously $[13,14]$.

\begin{tabular}{cccccc}
\hline Inhibitor & $\begin{array}{c}\Delta \boldsymbol{E}, \mathbf{V} \\
\text { at } \boldsymbol{C}_{\text {in }} \mathbf{1 . 6} \mathbf{~ m m o l} / \mathbf{l}\end{array}$ & $\begin{array}{c}\left(-\boldsymbol{\Delta} \boldsymbol{G}_{\mathbf{A}}^{\mathbf{0}}\right), \\
\mathbf{k J} / \mathbf{m o l}\end{array}$ & $\lg \boldsymbol{P}$ & $\mathbf{p} \boldsymbol{K}_{\mathbf{a}}$ & $\lg \boldsymbol{D}$ at $\mathbf{p H} \mathbf{7 . 4}$ \\
\hline $\mathrm{SOS}$ & 0.44 & $62 \pm 3.0$ & 7.00 & 3.77 & 3.61 \\
$\mathrm{NaC}_{12}$ & 0.25 & $64 \pm 3.0$ & 5.03 & 4.78 & 2.41 \\
$\mathrm{NaC}_{13}$ & 0.90 & $67 \pm 3.0$ & 5.56 & 4.78 & 2.97 \\
\hline
\end{tabular}




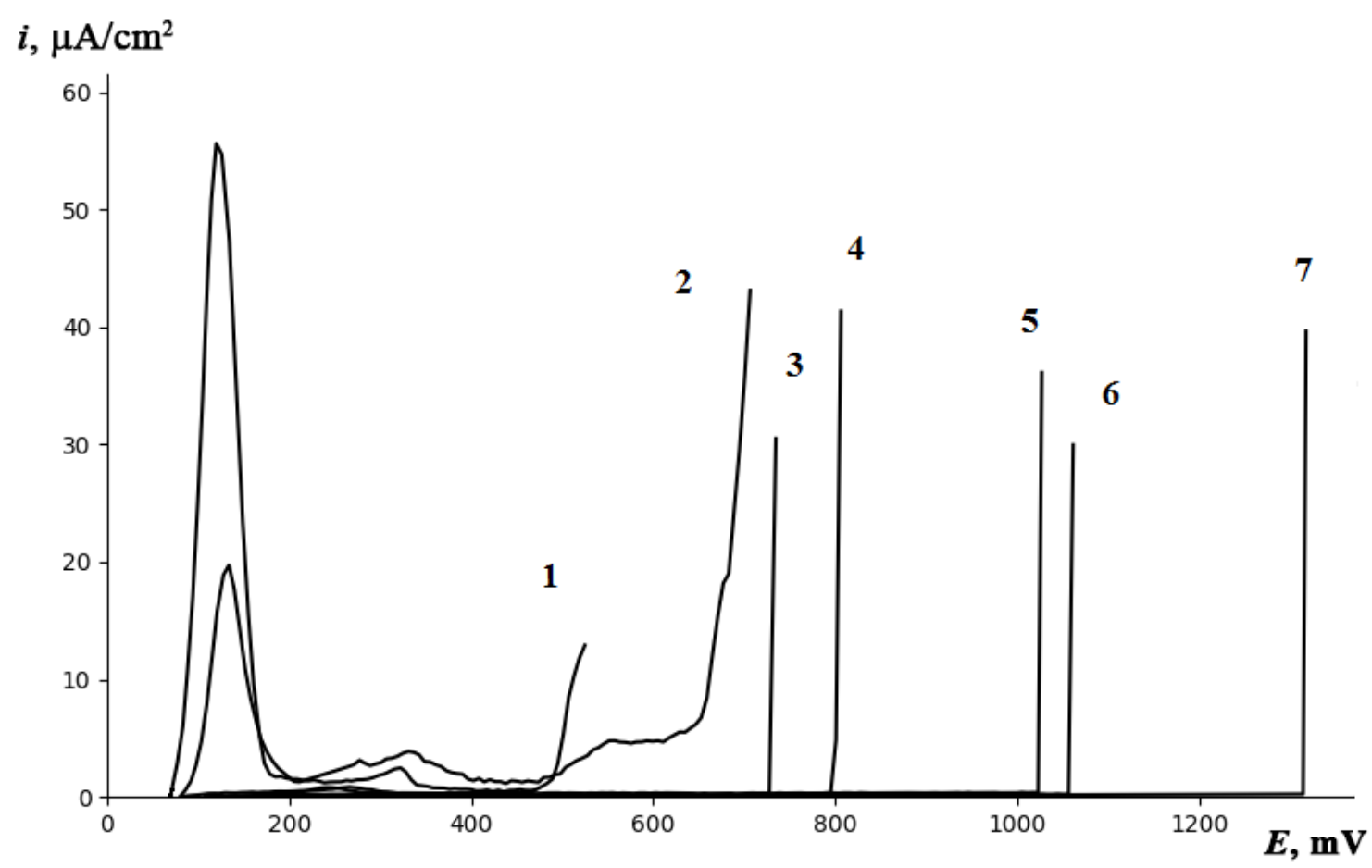

Figure 2. Anodic polarization curves of copper in borate buffer solution with $\mathrm{pH} 7.4$, in the presence of $10 \mathrm{mmol} \mathrm{NaCl}$ with sodium tridecanoate as $\mathrm{CI}(\mathrm{mmol} / \mathrm{l}): 1$ - background; 2 $0.07 ; 3-0.14 ; 4-0.24 ; 5-0.68 ; 6-1.3 ; 7-1.6$.

Severe accelerated corrosion tests in a humid atmosphere with daily condensation of moisture on copper samples showed that their five-minute passivation with inhibitor solutions at elevated temperatures, i.e. $t=60^{\circ} \mathrm{C}$, is more effective than at room temperature. This is especially apparent in copper passivation in a solution of $\mathrm{NaC}_{12}$ synthesized from technical lauric acid. Probably, it contains impurities of other alkanecarboxylic acids that enhance the passivating effect of laurate anions.

As already noted above, the passivating effect of higher carboxylates toward certain metals can be enhanced by combining them with small additions of TAS. Indeed, despite the fact that aminoethylaminopropyltrimethoxysilane itself (AEAPTS) does not protect copper from corrosion, an aqueous solution of its combination with $\mathrm{NaC}_{13}$ can be effective in passivating this metal. This is indicated already by the anodic polarization curves of copper shown in Figure 3.

Corrosion tests with daily condensation of moisture from passivated copper samples (Table 2) showed that the efficiency of this formulation with $C_{\mathrm{in}}=8.0$ or $16 \mathrm{mM}$ that forms ultra-thin protective films significantly exceeds that of films formed by $\mathrm{NaC}_{12}$ or $\mathrm{NaC}_{13}$. 


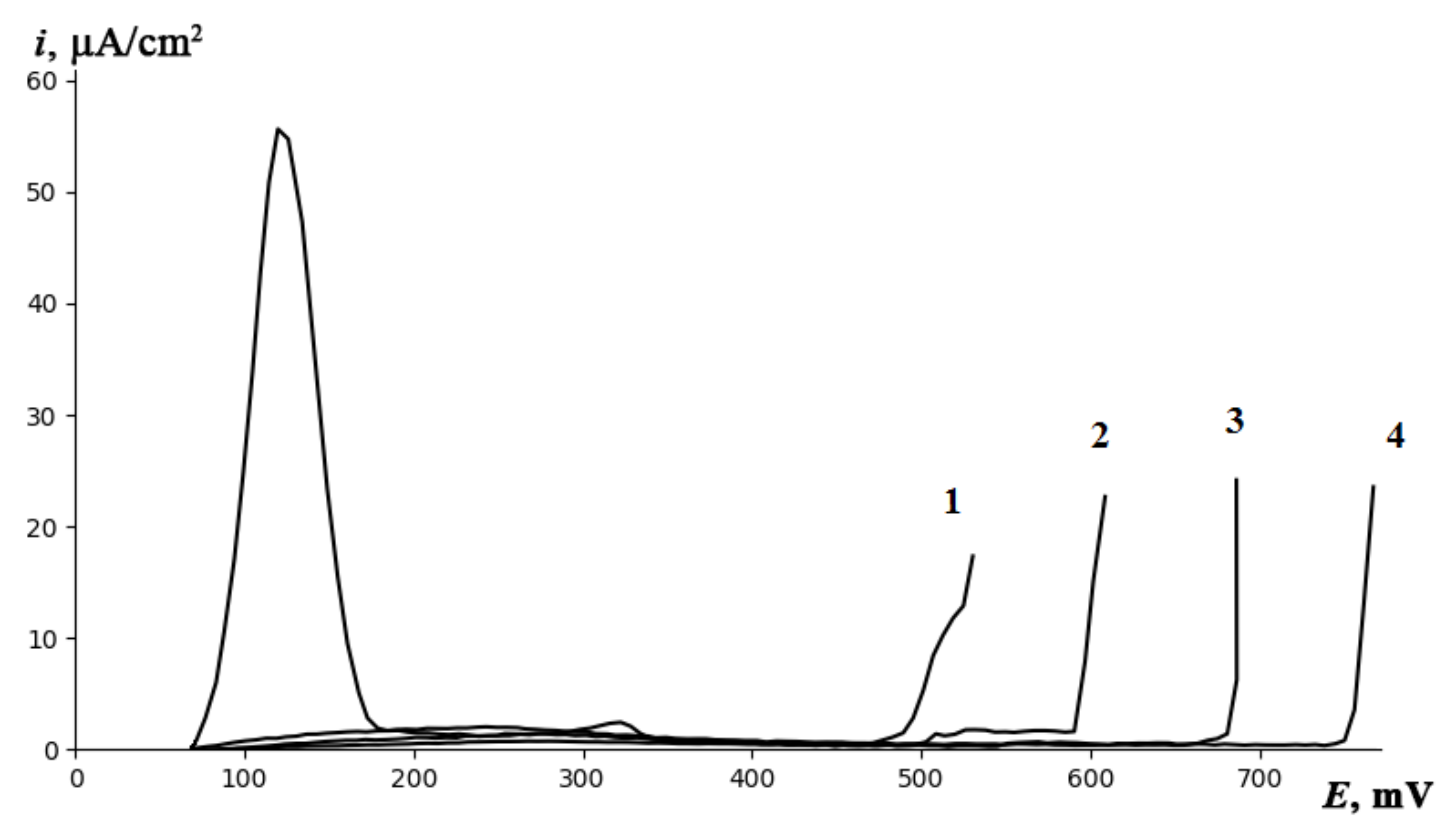

Figure 3. Anodic polarization curves of copper after keeping the electrode in the inhibitor solution for 5 minutes with $60^{\circ} \mathrm{C}$ in borate buffer solution with $\mathrm{pH} 7.4$, in the presence of $10 \mathrm{mmol} \mathrm{NaCl}$. Inhibitor mixture - sodium tridecanoate and TAS (mol/l): 1 - background; $2-1.5+0.5 ; 3-6+2 ; 4-12+4$.

Table 2. The results of corrosion tests of copper in a humid atmosphere with daily moisture condensation on samples pretreated in passivating aqueous solutions of organic corrosion inhibitors.

Passivating solution of $\mathrm{CI}$ (concentration in $\mathrm{mmol} / \mathrm{l}$ )
Time until the appearance of corrosion (days) on copper after its passivating treatment at $60^{\circ} \mathrm{C}$ for 5 minutes

\begin{tabular}{cl}
\hline Without inhibitor & $1.2 \pm 0.3$ \\
\hline $\mathrm{SOS}_{2} .0$ & $23 \pm 0.5$ \\
\hline $\mathrm{NaC}_{12}$ & $20 \pm 0.5$ \\
2.0 & $46 \pm 0.5$ \\
8.0 & $65 \pm 0.5$ \\
16.0 & \\
$\mathrm{NaC}_{13}$ & $13 \pm 0.5$ \\
2.0 & $19 \pm 0.5$ \\
8.0 & $24 \pm 0.5$ \\
16.0 & \\
\hline $\mathrm{NaC}_{13}+\mathrm{AEAPTS}$ & $62 \pm 0.5$ \\
$6.0+2.0$ & $75 \pm 0.5$ \\
\hline $12.0+4.0$ & \\
\hline
\end{tabular}




\section{Conclusions}

1. Sodium tridecanoate inhibits the active dissolution of copper in a neutral aqueous solution at $C_{\text {in }}=0.14 \mathrm{mmol} / \mathrm{l}$ and shifts the pitting potential to the oxygen evolution potential at a concentration of $1.6 \mathrm{mmol} / \mathrm{l}$.

2. The adsorption of sodium tridecanoate on copper at $E=0.0 \mathrm{~V}$ is polymolecular. The formation of the first monolayer inhibitor, already starting from a very low concentration $(0.01 \mathrm{nmol} / \mathrm{l})$, is described by the Temkin equation with a relatively high free energy of adsorption $\left(-\Delta G_{\mathrm{A}}^{0}\right)=67 \mathrm{~kJ} / \mathrm{mol}$, which suggests the possibility of chemisorption of tridecanoate.

3. Accelerated corrosion test of copper pretreated with an CI solution, in a humid atmosphere with daily moisture condensation on samples, showed that sodium tridecanoate is inferior in protective properties to some other inhibitors, but when it is used in combination with TAS at a molar ratio of $3: 1$, the protective properties are improved significantly.

\section{Acknowledgements}

This study was carried out at A.N. Frumkin Institute of Physical chemistry and electrochemistry of the Russian Academy of Sciences with support of the Russian Science Foundation (Grant No. 17-13-01413 "Fundamental principles of creation of ultrathin passivating organic films on metals for protection against atmospheric corrosion").

\section{References}

1. A.I. Altsybeeva and S.Z. Levin, Ingibitory korrozii metallov (Metal corrosion inhibitors), 1968, Leningrad, Khimiya, p. 264 (in Russian).

2. Yu.I. Kuznetsov, Organicheskie inhibitory korrozii metallov в neitralnykh vodnykh rastvorakh (Organic corrosion inhibitors of metals in neutral aqueous solutions), in: Korroziya i Zashchita ot korrozii (Itogi Nauki i Techniki) [Corrosion and Corrosion Prevention (Advances in Science and Technology)], Moscow, VINITI, 1978, vol. 7, 159-205 (in Russian).

3. Yu.I. Kuznetsov and L.P. Podgornova, Ingibirovanie korrozii metallov geterotsiklicheskimi khelatoreagentami (Inhibition of metal corrosion by heterocyclic chelate reagents), in: Korroziya $i$ Zashchita ot korrozii (Itogi Nauki i Techniki) [Corrosion and Corrosion Prevention (Advances in Science and Technology)], Moscow, VINITI, 1989, vol 15, 132-184 (in Russian).

4. Yu.I. Kuznetsov, Organic Inhibitors of Corrosion of Metals, Plenum Press, New YorkLondon, 1996, 283 pp.

5. Yu.I. Kuznetsov and L.P. Kazansky, Physicochemical aspects of metal protection by azoles, Russ. Chem. Rev., 2008, 77, no. 3, 219-232.

6. M. Finšgar and I. Milošev, Inhibition of copper corrosion by 1,2,3-benzotriazole: A review, Corros. Sci., 2010, 52, 2737-2749. 
7. M.B. Petrović Mihajlović and M.M. Antonijević, Copper Corrosion Inhibitors. Period 2008-2014. A Review, Int. J. Electrochem. Sci., 2015, 10, no. 2, 1027-1053.

8. Yu.I. Kuznetsov, Triazoles as a class of multifunctional corrosion inhibitors. A review. Part I. 1,2,3-Benzotriazole and its derivatives. Copper, zinc and their alloys. Int. J. Corros. Scale Inhib., 2018, 7, no. 3, 271-307. doi: 10.17675/2305-6894-2018-7-3-1

9. Yu.I. Kuznetsov, Organic corrosion inhibitors: Where are we now? A review. Part II. Passivation and the role of chemical structure of carboxylates, Int. J. Corros. Scale Inhib., 2016, 5, no. 4, 282-318. doi: 10.17675/2305-6894-2016-5-4-1

10. E. Rocca, G. Bertrand, C. Rapin and J.C. Labrune, Inhibition of copper aqueous corrosion by non-toxic linear sodium heptanoate: mechanism and ECAFM study, $J$. Electroanal. Chem., 2001, 503, no. 1-2, 133-140. doi: 10.1016/S0022-0728(01)00384-9

11. P. Wang, R. Qiua, D. Zhanga, Z. Lina and B. Hou, Fabricated superhydrophobic film with potentiostatic electrolysis method on copper for corrosion protection, Electrochim. Acta, 2010, 56, 517-522.

12. Yu.I. Kuznetsov, M.O. Agafonkina, N.P. Andreeva and L.P. Kazansky, Adsorption of dimegin and inhibition of copper dissolution in aqueous solutions, Corros. Sci., 2015, 100, 535-543. doi: 10.1016/j.corsci.2015.08.028

13. M.O. Agafonkina, Yu.I. Kuznetsov and N.P. Andreeva, Inhibitor Properties of Carboxylates and Their Adsorption on Copper from Aqueous Solutions, Russ. J. Phys. Chem. A, 2015, 89, no. 6, 1070-1076.

14. Yu.I. Kuznetsov, I.A. Kuznetsov and N.P. Andreeva, Formation of adsorption layers on copper from water solutions sodium laurate and their protective action in a humid atmosphere, Korroz.: mater., zashch., 2017, no. 4, 26-32 (in Russian).

15. K. Aramaki, Protection of zinc from corrosion by coverage with a hydrated cerium(III) oxide layer and ultrathin polymer films of a carboxylate self-assembled monolayer modified with alkyltriethoxysilanes, Corros. Sci., 2007, 49, 1963-1980.

16. A.M. Semiletov, Yu.I. Kuznetsov and A.A. Chirkunov, Inhibition of atmospheric corrosion of aluminum alloy (AMg6) by trialkxysilanes and their formulation with carboxylates, Korroz.: mater., zashch., 2016, no. 6, 29-36 (in Russian).

17. A.M. Semiletov, Yu.I. Kuznetsov and A.A. Chirkunov, Hydrophoization of the surface of AMg6 alloy and its protection from atmospheric corrosion by formulations of higher carboxylates and trialkoxysilanes, Korroz.: mater., zashch., 2017, no. 6, 2430 (in Russian).

18. M.O. Agafonkina, N.P. Andreeva, Yu.I. Kuznetsov and S.F. Timashev, Substituted Benzotriazoles as Inhibitors of Copper Corrosion in Buffer Borate Solutions, Russ. J. Phys. Chem. A., 2017, 91, no. 8, 1410-1417.

19. C. Hanch and A. Leo, Substituent Constants for Correlation Analysis in Chemistry and Biology, Wiley-Interscience, New York, 1979, 339 pp.

20. R.A. Scherrer and S.M. Howard. J. Med. Chem., 1977, 20, no. 1, 53-58. 